\title{
Da representação linguística à exacerbação iconográfica: as várias faces do vampiro Drácula na literatura, cinema e televisão
}

\author{
Jonathas Martins Nunes ${ }^{1}$ \\ Carlos Félix ${ }^{2}$
}

\begin{abstract}
Resumo: Nesta pesquisa, objetivamos o mapeamento das configurações representativas do vampiro na obra literária Dracula (1897), do escritor irlandês Bram Stoker, e a conversão transmidiática dessas configurações para adaptações cinematográficas como: o filme Alemão Nosferatu, eine Symphonie des Grauens (1922), o filme Bram Stoker's Dracula (1992), a série de filmes The Twilight Saga e a série de televisão Drácula (2013). A partir do exame comparativo tensionado entre as obras citadas, propomos a investigação e análise dos procedimentos e influências estabelecidas pela indústria cinematográfica no processo de adaptação/recriação dos estereótipos característicos do vampiro literário, latentes na personagem Drácula, para representações iconográficas em mídias visuais - cinema e televisão. Desta forma, reconhecendo os aparatos estilísticos do cinema, este trabalho teve seu foco voltado para as variações de imagem/representações do vampiro Drácula, baseando-se na hipótese de que, ao longo de suas recriações, a personagem delineada por Stoker tem algumas de suas características exacerbadas na linguagem visual cinematográfica.
\end{abstract}

Palavras-chave: Drácula. Literatura comparada. Iconografia. Teoria Crítica.

\section{Da representação linguística à exacerbação iconográfica: as várias faces do vampiro Drácula na literatura, cinema e televisão}

\begin{abstract}
In this paper, we aimed to map the Vampire representative configurations in Dracula (1897) written by Bram Stoker and its transmedia conversion to film adaptations, such as: the German film Nosferatu, eine Symphonie des Grauens (1922), the movie Bram Stoker's Dracula (1992), the film series The Twilight Saga and the television series Dracula (2013). From the comparative examination tensioned among the works cited, we propose a research and analysis of procedures and influences established by the film industry in the process of adaptation / re-creation of the characteristic stereotypes of the literary vampire, latent in Dracula, to iconic representations on the visual media - film and television. Thus, recognizing the stylistic devices of cinema, this paper focuses on the image variations/representations of the vampire Dracula, based on the hypothesis that throughout his recreations the character outlined by Stoker has some of its features exacerbated in cinematic visual language.
\end{abstract}

Keywords: Dracula. Comparative literature. Iconography. Critical Theory.

\footnotetext{
${ }^{1}$ Graduando em Letras Língua Inglesa pela Universidade do Estado da Bahia - UNEB, Bolsista de Iniciação Científica (FAPESB), pesquisador do grupo Desleituras em série: da tradução como transcriação, adaptação, refração, diáspora (UNEB). Email: jonathasmn23@gmail.com.

${ }^{2}$ Docente Adjunto da Universidade do Estado da Bahia (UNEB/Campus IV), professor permanente do Programa de Pós-Graduação em Crítica Cultura. Pesquisador pelo grupo Pós-Teoria, UNEB/PÓS-CRÍTICA. Email: jcfelixjuranda@yahoo.com.br.
}

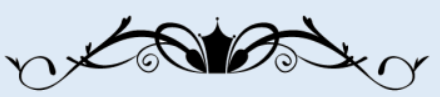




\section{Revista Letras Raras}

ISSN: 2317-2347 - Vol. 8, Ano 4, № 3 - 2015

\section{Introdução}

O vampiro tem sido uma das personagens mais retratadas e adaptadas de obras literárias para as telas do cinema e séries televisivas. Esta conversão transmidiática conferiu à sua figura um status canônico advindo de um processo de constante atualização, modulada seja por finalidades artísticas e/ou mercadológicas. Desde sua origem, podemos identificar movimentos transitórios que delinearam a temática e a personagem vampírica, a qual perpassa a tradição oral, mítica popular medieval e, na modernidade, se desenvolve por meio dos mais diversos gêneros literários - desde relatos médicos e exploratórios à poesia e narrativa literária ficcional.

Apesar de existirem várias obras literárias e escritos datados mesmo antes do século XV que abordam e exploram a temática do vampiro e suas características, é entre os séculos XVIII e XIX que encontramos um vampiro já mais delineado no campo da criação literária no sentido estrito ficcional. Carvalho (2010) aponta que antes desse período, haviam diversas obras literárias ficcionais em torno do vampirismo, porém, estas apresentavam-se de forma embrionária, isto é, personagens difusas que continham características assemelhadas, posteriormente imputáveis à personagem que hoje faz parte do imaginário popular (CARVALHO, p. 14).

No que diz respeito à produção ocidental do século XIX, trata-se de um cânone quase indiscutível as figuras criadas pelos escritores irlandeses Joseph Sheridan Le Fanu na obra Carmilla (1872) e o vampiro retratado em Drácula (1897) do autor Bram Stoker. Nessas duas obras em especial, podemos identificar a estratégia de escrita dos autores de retomarem em suas narrativas toda uma tradição popular e literária sobre o vampirismo, ao mesmo tempo em que acrescentam características, temáticas e contextualizações históricas de sua época sob essa personagem. Contudo, é na figura do conde Drácula do romance de Stoker que nos deparamos com os contornos mais nítidos daquilo que viria a se tornar a representação canônica e posteriormente icônica do vampiro ao decorrer do século seguinte - não apenas nas produções literárias como também no cinema mainstream ${ }^{3}$. De modo semelhante ao ocorrido com o Lord Ruthven do conto The vampyre (1819) de John William Polidori - qual

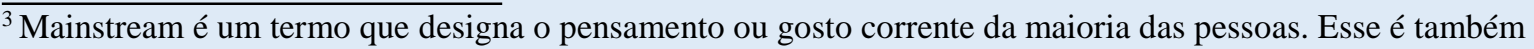
utilizado para referir-se as artes em geral, as quais são disseminadas pelos meios de comunicação em massa.
}

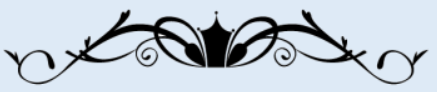




\section{Revista Letras Raras}

ISSN: 2317-2347 - Vol. 8, Ano 4, № 3 - 2015

serviu de base e desencadeou adaptações teatrais, literárias e óperas em torno do vampiro ao longo do século XIX - a personagem Drácula e suas características assumiram para o século XX a própria identidade do vampiro no imaginário popular, pois boa parte das variações posteriores advém de sua figura de base.

Ao longo do século XX, podemos notar uma vasta produção escrita em torno do vampiro, contudo, seu território preferencial será então o cinema - a mídia narrativa por excelência do século em questão. Apesar de seu idioma tecnicamente controlado, o cinema uma das expressões mais sintomáticas da indústria cultural - vem contribuindo para o desenvolvimento temático e característico da personagem vampírica, por meio de suas representações visuais iconográficas. A partir de adaptações fílmicas baseadas na personagem do romance Drácula (1897), como por exemplo, o filme alemão Nosferatu, eine Symphonie des Grauens (1922), dirigido por Friedrich Wilhelm Murnau, temos o início de um processo de materialização iconográfica dessa personagem, ou seja, o câmbio das descrições feitas no livro de Stoker por meio da narrativa para as imagens de uma mídia visual, mantendo suas características sombrias, monstruosas e diabólicas, acrescentando uma dimensão de sedução e a lascívia - características que constituem a figura e o imaginário popular do vampiro ao longo do século XX. Contudo, a partir de filmes como Bram Stoker's Dracula (1992), dirigido por Francis Ford Coppola, podemos notar determinadas mudanças nos traços físicos e psíquicos da personagem vampírica, interpretada pelo ator Gary Oldman, mudanças que sugerem certa tentativa de delineações paramentais do personagem entre mídias visuais. Tal tentativa de delineação das características da figura do vampiro não só mantem o traçado de uma personagem Heroico/protagonista romântico, mas também tendências estéticas e comportamentais da década de 1990, época em que foi lançado o filme.

Além dos filmes acima citados, também temos, mais recentemente, a série de filmes The Twilight Saga, dirigido por Catherine Hardwicke, que apresenta outra faceta da perspectiva contemporânea do vampiro, não só em termos físicos e imagéticos, mas pautadas em dilemas morais comuns ao ser humano contemporâneo sobrepostos sobre seus aspectos vampirescos - levando a este ser outro teor monstruoso a ser analisado durante este trabalho. Outra particularidade pertinente da série de filmes Twilight, em especial, e de sua personagem vampírica, é a recepção eufórica de seu público alvo, que se identifica com a personagem, a

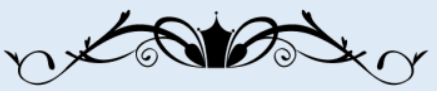




\section{Revista Letras Raras}

ISSN: 2317-2347 - Vol. 8, Ano 4, № 3 - 2015

qual está associada ao terror gótico e aos aspectos característicos de um monstro de fronteira (des)humano que carrega em si todos os estereótipos do monstro vampiro, mesmo que não idealizados na personagem em questão.

Por meio destas reformulações identificadas nas mídias visuais e literária em que o vampiro se apresenta, buscamos analisar ao decorrer deste texto quais os procedimentos e influências estabelecidas pela indústria cultural no processo de adaptação/recriação dos estereótipos característicos do vampiro, latentes na personagem Drácula, para representações iconográficas em mídias visuais - cinema e televisão. Para tanto, examinaremos o vampiro do livro Drácula (1897), do escritor irlandês Bram Stoker, e algumas de suas adaptações cinematográficas como: o filme Alemão Nosferatu, eine Symphonie des Grauens (1922), dirigido por Friedrich Wilhelm Murnau, o filme Bram Stoker's Dracula (1992), dirigido por Francis Ford Coppola, a série de filmes The Twilight Saga, dirigido por Catherine Hardwicke e baseado nos romances de Stephenie Meyer e a série de televisão Drácula(2013), produzida pela NBC Universal television. Assim, optaremos por uma análise formal e contextual, mobilizando conceitos que podem ser utilizados nas análises fílmicas e literária, as quais mesclam teorias sobre a estruturação do texto ficcional e da personagem por meio da narrativa em Rosenfeld (2007) e Candido (2007) à crítica de adaptação entre cinema e literatura, embasados nos estudos de Johnson (1982). Por fim, para a formação de uma possível hipótese de delineação do vampiro ao longo de seu percurso no cinema, teremos como pontos fulcrais a noção de monstro estabelecida por Bellei (2000) e os debates estabelecidos pela Teoria Crítica acerca dos mecanismos e estratégias de produção dos produtos culturais, com base em Adorno (1994). A análise estrutural dos objetos, da qual o presente trabalho participa, não é um fim em si, senão um meio, um método que deve levar posteriormente a uma teoria social mais abrangente e reflexões sobre as várias questões referentes ao papel da cultura de massas e a arte na sociedade contemporânea.

\section{A Construção Do Vampiro Na Literatura: Um Breve Panorama}

Os monstros vampirescos são exemplos de personagens que flutuam sobre a literatura e, consequentemente, ao longo do tempo, vão tomando forma por meio da grafia. As

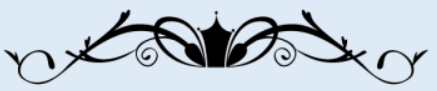




\section{Revista Letras Raras}

ISSN: 2317-2347 - Vol. 8, Ano 4, № 3 - 2015

primeiras crônicas medievais ou tardo-medievais a tratarem de figuras em que poderíamos reconhecer algo de vampiresco abordam o ser vampiro de maneira um tanto indireta e vaga. Segundo Carvalho (2010, p. 15), um dos poucos exemplos de obras a tratarem diretamente dessa personagem seria um documento russo em que surge a denominação Upir em 1047. Escritos como a crônica inglesa Historia rerum anglicarum de William of Newburgh no século XII, as crônicas tchecas de Jan Neplach no século XVI, ou a voga editorial da virada dos séculos XV-XVI, que explorou o anedotário em torno de Vlad Tepes, mais conhecido como Vlad Empalador ou Drácula, também refletiram e ajudaram a fixar uma tradição oral, baseada em mitos populares. Apesar das obras acima citadas tratarem de mortos-vivos, não ainda o vampiro em sentido moderno, podemos notar que certas associações já começavam a se delinear, contribuindo para a formulação da noção do vampiro como a conhecemos hodiernamente.

No entanto é entre os séculos XVII e XVIII que vemos a figura do vampiro tomar contornos mais delineados. Os primeiros gêneros literários em que surge o vampiro são a crônica, a dissertação e os relatos de viagens. Carvalho (2010) aponta que esses textos do início da Era Moderna - gêneros não ficcionais - nos apresentam o vampiro não enquanto um fenômeno literário, mas na forma de relatos que especulavam a possível real existência dessa personagem (CARVALHO, 2010, p.15). Num processo análogo à escrita da obra Drácula, as obras precedentes ao século XVIII são compendiadas e sintetizadas num livro que rapidamente adquire grande notoriedade, intitulado Dissertation sur les apparitions des anges, des démons et des esprits, et sur les revenans et vampires de Hongrie, de Bohême, de Moravie et de Silésie (1746) do Clérigo francês dom Augustin Calmet. Apesar de sua pretensão documental e realista, na sessão Dissertação sobre os regressantes em corpo, os Excomungados, os Upiros ou Vampiros, Brucolaques \&c, ao tentar diferenciar tais monstros referidos no título de outros tipos de demônios, Dom Calmet toma como base relatos e ditos populares, como podemos verificar no de trecho do capítulo XII, quando este utiliza sentenças como "Eu fui informado pelo falecido" e "foi informado pelo rumor público" (CALMET, 2010, p. 27), o que de certa forma, evidencia o uso do conhecimento popular sobre os assuntos abordados em sua obra:

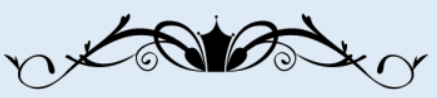




\section{Revista Letras Raras}

ISSN: 2317-2347 - Vol. 8, Ano 4, № 3 - 2015

Eu fui informado pelo falecido Sr. De Vassimont, Conselheiro da Câmara de Contas de Bar, que, tendo sido enviado por Sua Alteza Real Leopoldo I, o falecido Duque da Lorena, para tratar de negócios do Monsenhor Príncipe Carlos, seu irmão, Bispo de Olmütz e de Osnabruch, foi informado pelo rumor público que era bastante comum naquele País ver homens mortos algum tempo antes [...]. Este fato foi confirmado por várias pessoas, entre outros por um velho Pároco que dizia ter visto mais de um exemplo disso. (CALMET, 2010, p. 27)

O que podemos notar não só neste trecho específico como ao decorrer do capítulo citado é que, na tentativa de legitimação de possíveis fatos, baseada apenas em relatos e obras literárias anteriores, o livro de Dom Calmet se torna uma obra de teor ficcional. O que é interessante também ressaltar nessa obra, e em outras obras que retomam a monstruosidade do vampiro baseado em possíveis acontecimentos e/ou relatos, é a tentativa de racionalização do irracional - que se aplica ao imaginário do monstruoso - que está na ou para além da fronteira do conhecimento humano. Como bem observado por Bellei (2000, p. 11) em Definindo o monstruoso: forma e função histórica, a monstruosidade historicamente está relacionada com a criatura que se encontra na ou além da fronteira, paradoxalmente próximo e afastada do humano. Bellei também nos chama atenção para o fato que o monstro quando associado ao conceito de fronteira, atende a necessidades históricas diversas e pode ser utilizada como um instrumento para uma melhor compreensão dessas necessidades (BELLEI, 2000, p. 14). Em 1755, por exemplo, a imperatriz Maria Tereza, após o envio de um médico e um anatomista para esclarecer um caso de vampirismo na Morávia, decide confiar a investigação para o doutor Gerard van Swieten, que resume seus relatos no Discurso sobre a existência de fantasmas e seu Relato médico sobre os vampiros (1755) em uma tentativa de desmistificação do mito. Contudo, Carvalho aponta que Van Swieten era um médico do mais alto calibre, e não importava que seu esforço iluminista fosse de desmistificação e combate à superstição, o próprio fato de ter-se dedicado com seriedade ao tema já é um sintoma patente do grau com que tais crenças, ao menos para algumas populações, encontravam-se então disseminadas. (CARVALHO, 2010, p.17). Com isso, podemos notar em primeira instância que as tentativas de delineações do vampiro em obras escritas já se apresentam difusas: ao não empregarem ou negarem a existência do mítico, ou apenas por ter essa vertente do mito como base de racionalização do imaginário do monstro.

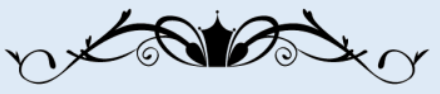




\section{Revista Letras Raras}

ISSN: 2317-2347 - Vol. 8, Ano 4, № 3 - 2015

No campo da criação literária ocidental, tomado em sentido estrito, o vampiro surge de forma eminente na poesia, entre os séculos XVII e XIX. Publicado em alemão na revista Der Naturforscher, o poema Crê a moça minha amada $(1748)^{4}$, também referido com o título Der vampir, do autor Heinrich August Ossenfelder, já estabelece elementos que serão retomados centenas de vezes na trajetória do vampiro literário ao decorrer dos séculos:

"Crê a moça minha amada",

Firme, austera e fielmente,

"Nas lições" ofertadas

"Da mãe sempre devota;"

"Como a gente do Tisza"

Crê em letais vampiros

Fielmente, feito "heiduques".

Cristininha, ora, espera,

Pois me amar tu não queres;

"De ti quero eu vingar-me,"

E de um "Tokayer", hoje,

"Beber a um vampiro".

E, "ao dormires" suave,

Te sorve à formosa

Face a púrpura fresca.

Tu te assombrarás logo,

Quando for eu "beijar-te",

Qual vampiro a beijar-te;

Então, quando temeres

"E mortiça em meus braços

Decaíres qual defunta",

Quererei perguntar-te:

Mi'as lições são melhores

Que as da boa mãe tua? (OSSENFELDER, 2010, p. 45)

As palavras e sentenças no poema acima destacados são exemplos característicos das possíveis ações e limitações de um vampiro, que são retomados posteriormente ao longo da ${ }^{4}$ Titilio original: Mein liebes Magdchen glaubet

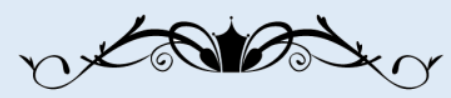




\section{Revista Letras Raras}

ISSN: 2317-2347 - Vol. 8, Ano 4, № 3 - 2015

história literária desse monstro. Tais características constituem: o apelo erótico, a localização culturalmente exótica, a figura da mãe da vítima, o lânguido ataque durante o sono, o sanguinário beijo/mordida do vampiro e a associação com o vinho/sangue. De certa forma, Ossenfelder também faz uma ponte entre os gêneros teóricos sobre a temática do monstro vampiresco - os quais o autor possivelmente utilizou como fonte - e o discurso da criação artística, visto que o periódico Der Naturforscher era de cunho cientificista. Contudo, vale também ressaltar que apesar de tantas características latentes no poema, a noção de vampiro ainda se encontra no campo do sobrenatural e irracionalizado, pois, temos somente uma conexão indireta das ações com quem comete os atos e, acesso à voz narrativa/eu lírico - a qual não perpassa a fronteira do irreconhecível.

Segundo Carvalho (2010, p.19), o tema vampiro entra de forma definitiva para o cânone a partir da publicação da balada de Gottfried August Bürger, Lenore (1773). Mas a figura vampiresca retratada no poema em questão, não se trata de um vampiro com características ainda bem delineadas, e sim de um morto-vivo que rapta a sua amada. Além de ilustrar características da personagem que aqui nos interessa, o poema Lenore começou a formar, ao longo das décadas seguintes, exatamente o que pode ser chamado de um "gosto" que consequentemente estimulou o interesse do público leitor para o assunto - resultando, a partir de 1790, em sete versões e adaptações para o inglês. Esse processo também evidenciou a expansão e potencialidade de um possível consumo mercadológico da personagem e temática do vampiro na literatura.

Perpassando todo esse período histórico de criaturas mal discerníveis às figuras semelhantes ao vampiro, é na modernidade que a personagem vampírica vem a se delinear com mais especificidade e será tomada como motivo ou tema da criação literária propriamente dita. É também nesse período que teremos a aparição/invenção do vampiro narrativo por meio do conto The vampyre (1819) de John William Polidori. A publicação de The vampyre e sua personagem Lord Ruthven dão início à primeira febre do vampiro ficcional na Inglaterra. Tal feito será levado às massas com sua adaptação para o teatro, $L e$ vampire (1820), escrito por Charles Nodier, dando início a um processo de popularização da figura do vampiro ao decorrer do século. Carvalho (2010, p. 19) nota que quase que concomitantemente ao surgimento do melodrama Le vampire, aparece também sua paródia,

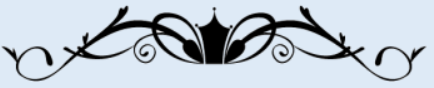




\section{Revista Letras Raras}

ISSN: 2317-2347 - Vol. 8, Ano 4, № 3 - 2015

apenas dois dias depois, que satirizava o enredo de Nodier. Desse modo, sucedem-se muitas peças e apropriações pelas décadas seguintes e o palco torna-se um domínio privilegiado para o vampiro - qual ganha o gosto popular. Assim, é evidente aqui um fenômeno de suma importância para o seu desenvolvimento posterior, lançando as bases para sua futura exploração cinematográfica.

Os propulsores seguintes do mito e cânone da figuração do vampiro, ainda no final do século XIX, são as obras dos escritores irlandeses, Carmilla (1872), de Joseph Sheridan Le Fanu, e o vampiro retratado em Drácula (1897), de Bram Stoker. Tomando ainda a metáfora e/ou conceito de monstro de fronteira empregado ao monstro vampiresco - a monstruosidade que está para/na além da fronteira - podemos notar nas obras citadas ao decorrer desta sessão, que houve por parte de alguns dos autores a tentativa de verbalizar/delinear/legitimar aquilo que não tinha sido racionalizado. Algumas dessas obras tentam delinear o vampiro por meio do misticismo ou acentuando a preponderância da ciência - inviabilizando uma possível dialética entre mito e ciência ao desenhar suas personagens, tornando a caricatura do vampiro difusa. Contudo, Drácula (1897) apresenta um vampiro tanto característico como espacialmente estruturado, retomando em sua narrativa boa parte da tradição científica, mítica, teatral e literária em torno do vampiro. Dessa forma, Drácula fecha um ciclo de tentativas difusas, ao longo dos séculos, por obras anteriores, e formula a figuração literária canônica do vampiro ao longo do século seguinte. Como será observado daqui por diante, a figura do vampiro surgirá ciclicamente e servirá não apenas aos propósitos da criação artística, mas também aos da sua exploração mercadológica.

\section{Drácula e a gramática do vampiro na literatura}

Ao lermos a obra Drácula (1897), podemos identificar diversas influências de seus antecessores, moldadas na personagem do conde que carrega o nome do livro de Bram Stoker. No entanto, a obra em questão não só retoma uma tradição literária e caracterizações referentes ao vampiro, mas também funciona, ao seu modo, como parâmetro de monstro vampiresco - muito bem delineado ao decorrer de seu enredo - que servirá de base tanto para obras literárias posteriores como para as reproduções iconográficas do vampiro entre as

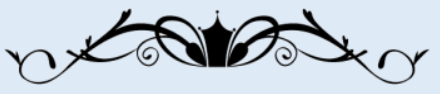




\section{Revista Letras Raras}

ISSN: 2317-2347 - Vol. 8, Ano 4, № 3 - 2015

mídias visuais. A seguir, veremos que o vampiro Drácula pode tudo, porém, dentro de um rigoroso sistema de regras - ao qual chamamos no título dessa sessão de gramática do monstro vampiresco e mais à frente de "gramatização" desse monstro em Drácula.

É perceptível no romance de Bram Stoker que o enredo e sua personagem vampírica são estruturados por meio de uma miríade de molduras, presentes na estruturação epistolar e sua modulação narrativa: relatos, cartas, jornais e narrações, na maior parte das vezes, em primeira pessoa - dando certa possibilidade de significação/realismo do conteúdo. De forma processual, a figura da personagem é moldurada como um ser para além da fronteira que precisa ser racionalizado por meio dos eventos/relatos - conferindo-lhe características que possibilitam a constituição de uma "gramática/normatização" do que vêm a ser um vampiro. Logo no capítulo inicial, em que Jonathan Harker descreve alguns dos acontecimentos de sua viajem a negócios, podemos identificar temas que permeiam a temática do vampiro, como: a cultura exótica e bárbara, a crença folclórica, o misticismo, acontecimentos sobrenaturais, o castelo/covil sombrio - que são constituídos pelo imaginário popular. É também nesse início que temos a primeira descrição do vampiro em termos físicos, pela personagem Jonathan Harker que, ao chegar no castelo do conde, depara-se com a personificação do monstro:

Seu rosto era enérgico, muito enérgico e másculo, o nariz fino era aquilino e as narinas eram peculiarmente arqueadas. A testa formava uma curva arrogante e o cabelo crescia escasso ao redor das têmporas, porém aparecia em profusão em todos os outros locais. Suas sobrancelhas eram muito espessas e quase se uniam sobre o nariz, formadas por bastos pelos que pareciam encaracolar-se devido à sua profusão. O pouco que via de sua boca, pois um grosso bigode a escondia, indicava-me que era séria e de aparência bastante cruel, apresentando dentes brancos particularmente afiados; estes se projetavam sobre os lábios, cuja extraordinária vermelhidão denotava surpreendente vitalidade para um homem já idoso. Quanto ao resto, suas orelhas eram pálidas, extremamente pontudas em cima; o queixo aparecia largo e enérgico e as faces denotavam firmeza, embora fossem finas. O efeito geral era de extraordinária palidez. (STOKER, p. 241)

Podemos notar que nesse trecho específico, encontramos alguns dos traços físicos característicos do vampiro, propagados ao longo do século XX pelo cinema, a saber: o rosto enérgico e másculo, a aparência bastante cruel, os dentes brancos afiados para fora da boca e a palidez anômala do corpo em contraste com a vermelhidão dos lábios que denotam vitalidade do corpo que está sob a condição de morto-vivo. Além dos traços físicos da personagem descritos acima, no trecho a seguir, em que a personagem John Seward relata em seu

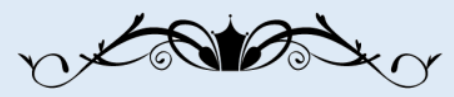




\section{Revista Letras Raras}

ISSN: 2317-2347 - Vol. 8, Ano 4, № 3 - 2015

fonógrafo os acontecimentos referentes ao paciente Renfield e suas estranhas ações diante de um morcego, podemos identificar a exploração de um dos elementos mais recorrentes do vampiro na literatura e posteriormente no cinema - a transfiguração de seu corpo em morcego:

Outra aventura noturna. Habitualmente, Renfield esperou que o guarda entrasse no quarto para inspecioná-lo. Em seguida, passou correndo por ele e atravessou com a máxima velocidade o corredor. Mais uma vez, foi ao terreno da casa deserta e o encontramos no mesmo lugar, comprimindo-se contra a porta da velha capela. Quando me viu ficou furioso e, se os guardas não o pegassem a tempo, teria tentado matar-me. Enquanto o segurávamos, algo estranho aconteceu. Repentinamente redobrou sua força e depois súbito se tornou calmo. Olhei ao meu redor instintivamente, mas nada vi. Então segui os olhos do doente, nada notando enquanto eles contemplavam o céu enluarado; avistei apenas um grande morcego que voava fantasmagórica e silenciosamente para o oeste. Os morcegos em geral fazem curvas, mas este pareceu ir em direção reta, como se soubesse para onde ir e como se tivesse vontade própria. (STOKER, p. 317)

Outros eventos no enredo também exploraram esses e outros tipos de plasticidade do vampiro, como por exemplo, o episódio da chegada do navio em Whitby, no qual o conde Drácula se transformou em um lobo para adentrar a cidade de Londres. Apesar desse elemento de plástica corpórea da personagem ser um dos mais recorrentes em obras literárias anteriores, poucas foram suas variações ao decorrer das aparições do vampiro literário - pois tais variações sempre recorriam à transfiguração desse ser em animais. Um dos acréscimos mais notáveis do monstro Drácula à figura do vampiro - e pouco explorada no cinema contemporâneo - é a extrapolação dessa capacidade de transfiguração de seu corpo, pois, além das transfigurações animalescas, a personagem também pode diminuir e aumentar de tamanho e se transforma em névoa, nuvem ou até mesmo em pó.

Apesar de termos em mente toda a esquematização processual da narrativa na construção da personagem vampírica, é no diário da personagem Mina Murray/Harker que são compendiadas todas as características do vampiro, listadas no romance. Neste trecho, é narrado o episódio em que a personagem Van Helsing teria feito o estudo de documentos, diários, anotações e relatos de eventos que envolviam o vampiro Drácula, a fim de mapeá-lo para posteriormente destruí-lo. Apesar de imprimir um método científico aos seus estudos,

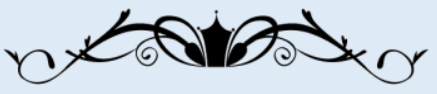




\section{Revista Letras Raras}

ISSN: 2317-2347 - Vol. 8, Ano 4, № 3 - 2015

podemos notar na citação a seguir que a personagem Van Helsing não deixa de referenciar a superstição e o mito como possíveis fontes para as conclusões sobre o caso estudado:

Para nossas conclusões, teremos de nos basear apenas em tradições e superstições, o que não parece muito quando o caso em questão é mais importante do que a vida ou morte. Contudo, devemos contentar-nos com esses dois elementos, em primeiro lugar porque não temos outros meios sob nosso controle e, em segundo lugar, porque afinal a tradição e a superstição são tudo. Embora o mesmo não ocorra conosco, não é verdade que os outros acreditam nos vampiros exclusivamente por causa desses dois elementos? Há um ano, qual de nós teria acreditado nessa possibilidade, no meio deste século XIX, realista, científico e cético? Rejeitamos até uma crença que vimos justificada diante dos nossos próprios olhos. (STOKER, 2012, p. 421)

Esse trecho também possibilita uma leitura dialética entre as duas fontes de conhecimento humano, até então não tensionadas em obras literárias referentes ao vampiro: a ciência aplicada aos métodos de Van Helsing e a superstição e mitos advindos da cultura popular. Como observado, ao longo da construção do vampiro, tivemos séculos de conflitos entre o misticismo e a preponderância da ciência, retratadas nas obras literárias destacadas. Drácula, por sua vez, difere das demais obras ao construir a personagem por meio da articulação de três instâncias inicialmente em conflito: a primeira refere-se ao conhecimento popular e mitos sob o vampiro; a segunda à tradição literária; enquanto a terceira trabalha em consonância com as duas anteriores e pautada em parâmetros científicos, com a finalidade de mapear esse ser monstruoso.

Tal proposta de delineação mito-científica do vampiro, ainda na narrativa do diário da personagem Mina Murray/Harker, assinala outras instâncias de mapeamento do monstro a partir das quais a obra de Stoker estrutura-se: a esquematização das ações do monstro doravante gramatização. O trecho a seguir apresenta um conjunto de características constitutivas do vampiro com base não apenas em traços físicos, mas enquanto um ser que faz coisas/ações dentro de certas limitações:

O Nosferatu não morre como a abelha quando pica. É mais forte e por isso tem maior poder para fazer o mal. Esse vampiro que está entre nós tem a força de vinte homens; é mais astuto do que qualquer mortal, pois sua astúcia cresce com os séculos; é ainda auxiliado pela necromancia, que, como indica a etimologia, consiste na adivinhação por intermédio dos mortos, e todos estes, quando próximos dele, lhe obedecem. Ele é bruto e, mais do que isso, tão cruel quanto o diabo; pode, dentro de certos limites,

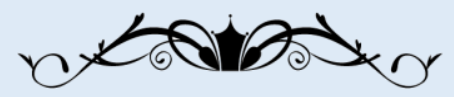




\section{Revista Letras Raras}

ISSN: 2317-2347 - Vol. 8, Ano 4, № 3 - 2015

aparecer quando, onde e sob qualquer forma que lhe convenha; pode também dentro de certos limites, dirigir os elementos: a tempestade, o nevoeiro, o trovão; pode comandar todos os animais vis: o rato, a coruja, o morcego, a mariposa e o lobo; pode crescer, diminuir e, às vezes, é capaz de desaparecer e aparecer sem ser visto. Como principiaremos então nossa luta para destruí-lo? Como encontraremos seu esconderijo e, uma vez descoberto este, como o eliminaremos? Meus amigos, o encargo que nos impusemos é terrível, e podem surgir consequências que farão os bravos tremerem. É que, se perdemos essa luta, ele ganhará; neste caso, qual será nosso fim? (STOKER, 2012, p. 420)

Seguindo essas delineações, além das características já apontadas, Van Helsing também pontua que o vampiro pode: 'desenvolve-se, fortalecendo-se com o sangue dos vivos'; 'pode até rejuvenescer'; 'reforçar suas faculdades vitais quando seu alimento especial se torna farto'; ' produzir nevoeiro e dentro dele chegar', porém podendo apenas ficar ao redor dele; 'surgir em raios do luar como poeira'; 'enxergar no escuro' (STOKER, 2012, p. 421). Ademais, Drácula estabelece um dos mais poderosos clichês do vampiro ao decorrer de suas aparições iconográficas no cinematográfico, 'a ausência do reflexo no espelho' e a 'ausência de sua sombra', descritas no diário de Jonathan quando ainda estava no castelo do conde. Diante dessa porção de coisas que o vampiro tem capacidade de fazer, ainda no diário de Mina Harker, na citação a seguir, a personagem Van Helsing também faz algumas considerações a respeito das limitações do vampiro:

Ah, mas ouçam o resto: tem todos esses poderes, mas não é livre; é mais prisioneiro do que um escravo nas galés ou do que um louco em uma cela. Não pode ir aonde deseja; não sabemos por que, ele, que não pertence à natureza, é obrigado a seguir algumas leis desta. Não pode entrar pela primeira vez em lugar algum, a não ser que o convidem, embora depois possa penetrar quando quiser. Seus poderes, como de todas as coisas más, cessam ao surgir do dia. Apenas em certas ocasiões tem liberdade limitada. Se não está no lugar a que pertence, só pode mudar ao meio-dia ou na hora exata do pôr do sol. Ouvimos essas coisas e nossos relatos apresentam disso provas indiretas. Assim, pode fazer o que deseja dentro de seus limites, quando está em sua casa terrena, no caixão, na casa infernal ou no lugar sacrílego, como vimos no túmulo do suicida em Whitby: contudo, em outras ocasiões, só pode modificar-se quando chega a hora. Dizem também que só pode atravessar água corrente quando a maré baixa. (STOKER, 2012, p. 421422)

Essa miríade de características opera no sentido de mapear o monstro, para a priori tirá-lo do campo do desconhecido e posteriormente dominá-lo. Além da gramatização do monstro, podemos notar na citação acima algumas das contribuições de Drácula (1897) para

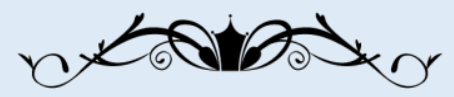




\section{Revista Letras Raras}

ISSN: 2317-2347 - Vol. 8, Ano 4, № 3 - 2015

o imaginário do vampiro retomadas ao longo do século XX. Tais contribuições referem-se também ao sistema de regras em que o vampiro é confinado, como por exemplo, sua relação anômala para com o dia/luz e a noite/trevas: de dia, não pode cruzar uma corrente de água sem ser levado ou carregado, como não pode mudar de forma; já durante a noite, molda seu corpo em uma gama de transfigurações.

Essas características até o momento sinalizadas são retomadas ou extrapoladas ao longo das adaptações do vampiro no cinema, o que fez com que ambos o personagem e obra Drácula se tornem a figura canônica do vampiro a ser lembrada no discurso moderno da monstruosidade e no imaginário popular. Apesar de também habitar uma vasta produção escrita entre os séculos seguintes, XX e XXI, o território preferencial do vampiro será o cinema - pautado em sua representação iconográfica. Assim, podemos dizer que a delineação do vampiro literário estava pautada preponderantemente nos limites de ação desse ser, e como veremos a seguir, no cinema sua delineação estará pautada na sua apresentação visual iconográfica - diferente das apresentações anteriores que eram pautadas majoritariamente em narrativas escritas.

\section{O Vampiro No Cinema: Fase Iconográfica}

Desde sua própria criação, o cinema tem se desenvolvido segundo linhas narrativas, apropriando-se de um número considerável de textos ficcionais como fonte primária de suas produções fílmicas. Nesse procedimento de adaptação, a indústria cinematográfica - ao decorrer de seu processo de construção - encontrou especificamente na literatura e no teatro do século XIX e início do século XX o modelo e conteúdo narrativo adequados para adaptálos à linguagem técnica do cinema. Por sua vez, a história do vampiro Drácula e seu processo de conversão para a mídia visual nascem no mesmo período em que o cinema se estabelece enquanto mídia narrativa.

Uma das primeiras tentativas de câmbio da narrativa e características do vampiro Drácula para o cinema é a adaptação livre Alemã Nosferatu, eine Symphonie des Grauens (1922), dirigidopor Friedrich Wilhelm Murnau. Embora Murnau e seu roteirista Galeen

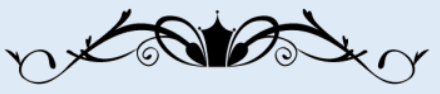




\section{Revista Letras Raras}

ISSN: 2317-2347 - Vol. 8, Ano 4, № 3 - 2015

tenham mudado os nomes das personagens e alguns detalhes ao decorrer de seu filme, estes foram acusados de plágio, pois os herdeiros que detinham os direitos da obra do escritor Bram Stoker não concederam aos produtores autorização para adaptar a obra. Apesar de se apropriar da obra de Stoker, a personagem Nosferatu de Murnau, ou melhor, sua versão do vampiro Drácula, também desenvolve um dos clichês mais retomados ao longo do percurso do vampiro no cinema: sua mortal fragilidade diante da luz solar. Como podemos observar na sequência de plano das Fig. 1 e 1.1, em que o vampiro Conde Orlok, interpretado por Max Schreck, vai até o quarto de sua vítima Ellen Hutter/Mina Harker, e depois de sugar seu sangue, se põe diante do sol que atravessa a janela, reduzindo seu corpo à cinzas em poucos segundos. Apesar dessa caraterística, que delimita o monstro vampiresco, já estar instalada no imaginário popular devido às inúmeras figurações do vampiro no cinema, Drácula, como pudemos observar anteriormente, possui certas limitações durante o dia, mas pode andar livremente sob a luz do sol - o que de certa forma difere dos estereótipos do vampiro estabelecidos ao longo do século XX.

Figura 1: Conde Orlok em contato com o sol

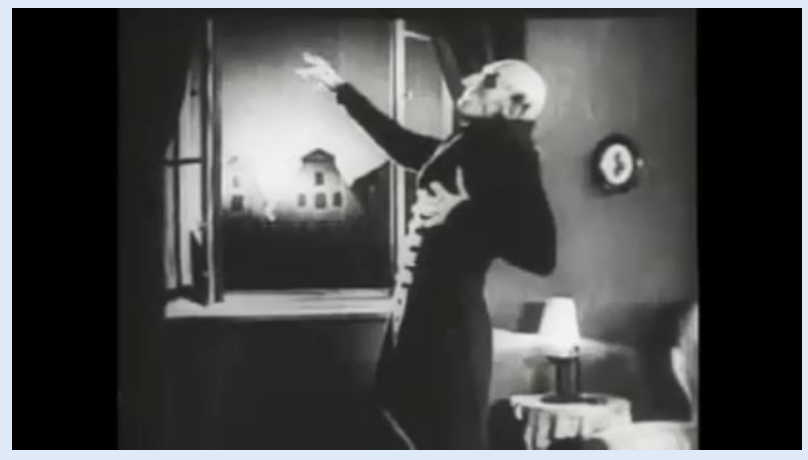

Figura 1.1: O Nosferatu destruído e evaporado pelo sol
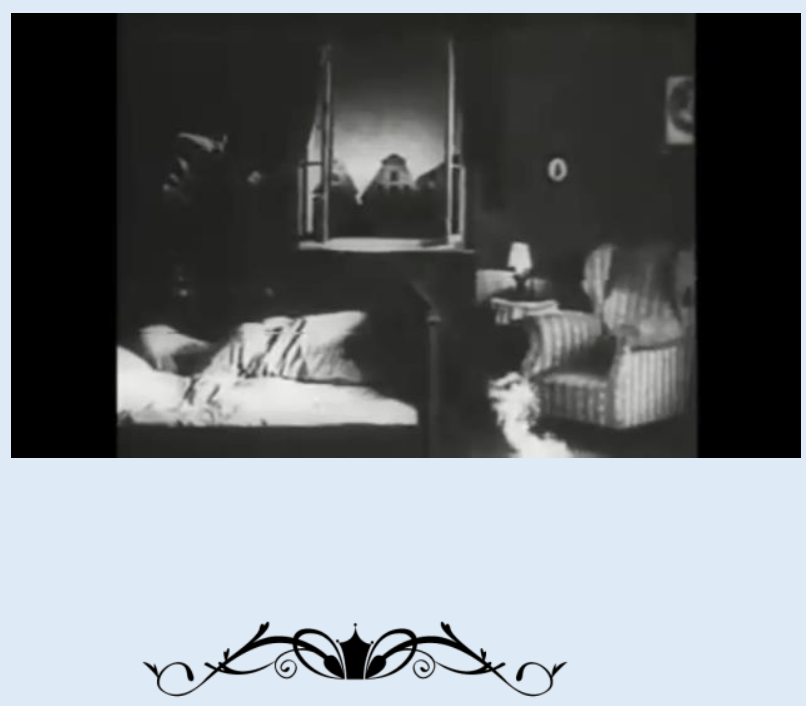


\section{Revista Letras Raras}

ISSN: 2317-2347 - Vol. 8, Ano 4, № 3 - 2015

Fonte: captura do filme Nosferatu, eine Symphonie des Grauens (1922)

Um elemento fundamental no estilo estético adotado por Murnau em Nosferatu foi a utilização sistemática de trucagens para mimetizar as características sobrenaturais do vampiro. Nessa sequência, Murnau estabelece uma reação entre os dois planos por meio da fusão, quando o primeiro plano (Fig. 1) é sucedido pelo segundo (fig. 1.1) de forma gradual, produzindo com isso uma interação do monstro com o aparelho cinematográfico - de reprodução tanto narrativa quanto simbólica. Dessa forma, e reconhecendo os aparatos estilísticos do cinema, teremos nosso foco voltado para as variações de imagem do vampiro Drácula, baseado na hipótese de que ao longo de suas aparições a personagem delineada por Stoker e suas características serão exacerbadas na linguagem visual cinematográfica. Para tanto, focaremos preponderantemente no vampiro e suas representações iconográficas, mapeando as tentativas pela qual o cinema torna o vampiro muito mais caricato/vampiresco do que os monstros retratados na mídia literária.

Ao decorrer do filme Nosferatu, podemos notar que em seu plano de composição narrativa há uma lógica mimética, a qual trabalha não só sob as ações que delinearam o vampiro na literatura, como também, sob a apresentação da própria personagem e a noção de monstro a este implicada. Isto é, o que de fato essa mimese retoma é a representação do vampiro enquanto um monstro sobrenatural. Como podemos verificar ainda na cena em que o conde vai ao quarto de Ellen Hutter na Fig. 1.2, sua representação é baseada por meio do jogo de luzes e sombra refletida, sugerindo um monstro vampiresco para além do que possamos identificar como humano.

Figura 1.2: Conde Orlok subindo as escadas em direção ao quarto de Ellen Hutter

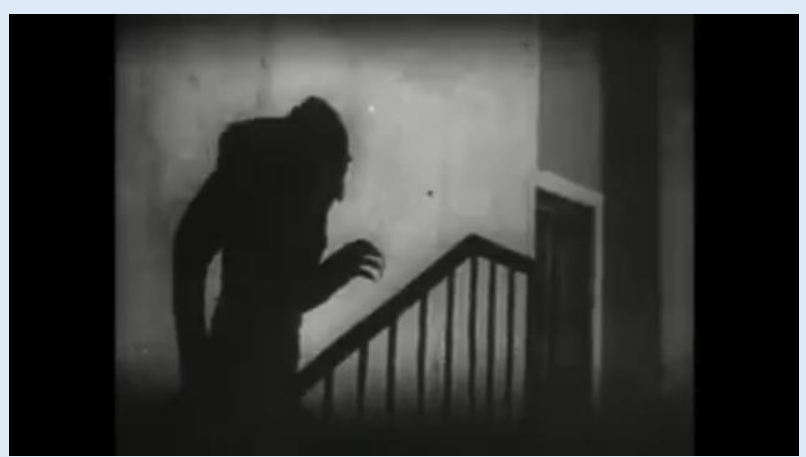

Fonte: captura do filme Nosferatu, eine Symphonie des Grauens (1922)

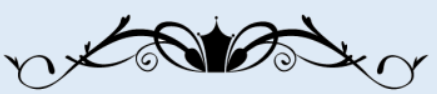




\section{Revista Letras Raras}

ISSN: 2317-2347 - Vol. 8, Ano 4, № 3 - 2015

Vale também ressaltar que Nosferatu não constitui a primeira adaptação do romance Drácula para o cinema. Mauro Pommer (2008) aponta que a primeira versão para o texto de Stoker foi o filme húngaro Drakula (1920), uma adaptação também não-autorizada da qual não restou nenhuma cópia conhecida (POMMER, 2008, p. 25). Apesar disso, a ascensão da caricatura do vampiro no cinema, parte dos traços monstruosos do ícone do conde Orlok, a qual retoma e extrapola a representação do monstro: como podemos observar na Fig. 1.3, na qual o vampiro termina de sugar o sangue da personagem Ellen. Nota-se nessa cena que as delineações físicas e imagéticas do monstruoso no vampiro, encarnadas em Nosferatu, estão para além da monstruosidade do vampiro Drácula.

Figura 1.3: Conde Orlok subindo as escadas em direção ao quarto de Ellen Hutter

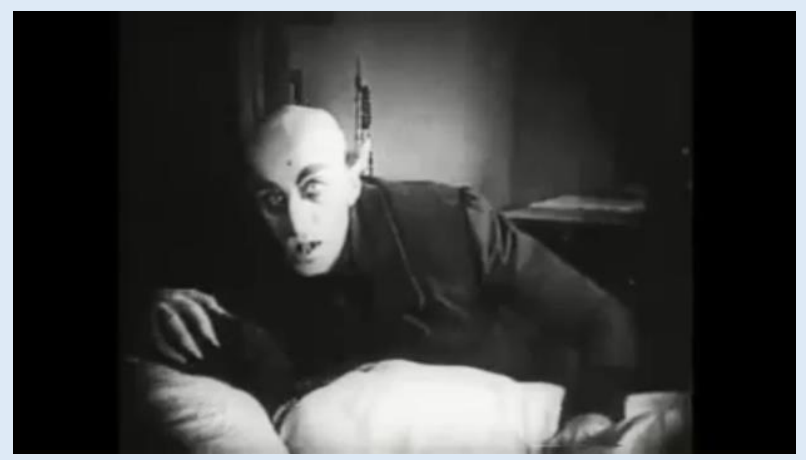

Fonte: captura do filme Nosferatu, eine Symphonie des Grauens (1922)

Outro filme que se propõe a retomar os traços delineados por Stoker é o filme Bram Stoker's Dracula (1992) do diretor Francis F. Coppola. Nesse filme, podemos notar determinadas mudanças nos traços físicos da personagem vampírica, interpretada pelo ator Gary Oldman, que retoma ambos os lados monstruoso e humanístico da personagem: ao basear-se na gramatização feita por Bram Stoker, em consonância com uma possível explicação e retomada do mito de Vlad Empalador, atribuindo uma simbologia heroica à personagem e seu caso amoroso com a personagem Mina Harker. Tal tentativa de delineação das características da figura do vampiro, por meio da iconografia, não só mantem o traçado de uma personagem heroico/dândi/protagonista romântico, mas diferencia o vampiro, ali tratado, de filmes B em que o vampiro se apresentava anteriormente, empregando e sugerindo certa tentativa de delineações paramentais do personagem entre mídias visuais. Apesar disso, em

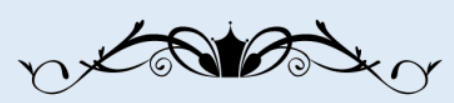




\section{Revista Letras Raras}

ISSN: 2317-2347 - Vol. 8, Ano 4, № 3 - 2015

um processo análogo à obra de Stoker, Coppola não sobrepõe sua filmografia e narrativa às demais realizadas, em vez disso: retoma a tradição narrativa do vampiro na literatura e a narrativa estilística das filmografias anteriores, as quais trabalham o monstro vampiresco por meio da mimese produzida pelos aparatos cinematográficos. Com isso, o Drácula de Bram Stoker projeta a verossimilhança ou credibilidade, do que é proposto em seu título, nos olhos de seus espectadores.

O primeiro momento em que as características do vampiro Drácula são transpostas e destacadas por sua representação iconográfica ocorre na cena em que Jonathan Harker chega ao castelo e se depara com a figura do Conde (Fig. 2), o qual apresenta em si o traçado do monstro vampírico delineado por Bram Stoker: rosto enérgico e pálido, por sinal muito enérgico e másculo, o nariz fino e aquilino, a testa curva, aparência bastante cruel, dentes brancos particularmente afiados e o efeito geral de extraordinária palidez/morte. A cena em que o conde persuade Lucy e em forma anômala e sexual suga o sangue da personagem (Fig. 2.1) explora o poder de transfiguração da personagem, transfigurado em uma espécie de lobomorcego-homem.

Figura 2: Conde Drácula se apresentado ao receber Harker em seu castelo.

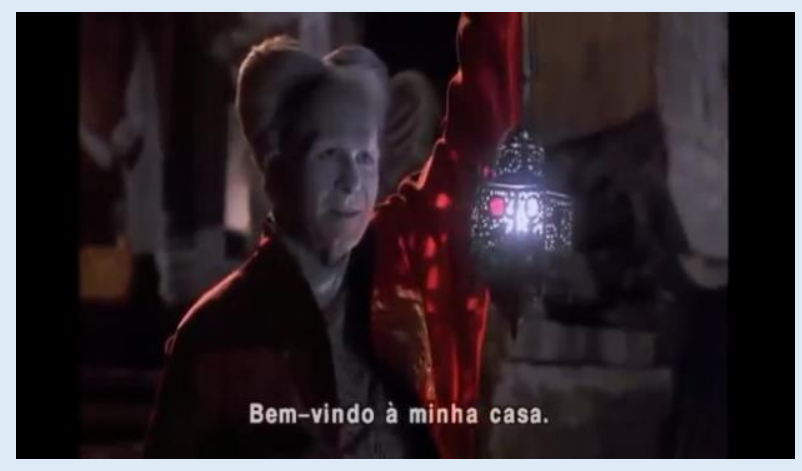

Figura 2.1: Conde Drácula "sugando" o sangue de Lucy.

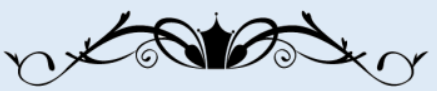




\section{Revista Letras Raras}

ISSN: 2317-2347 - Vol. 8, Ano 4, № 3 - 2015

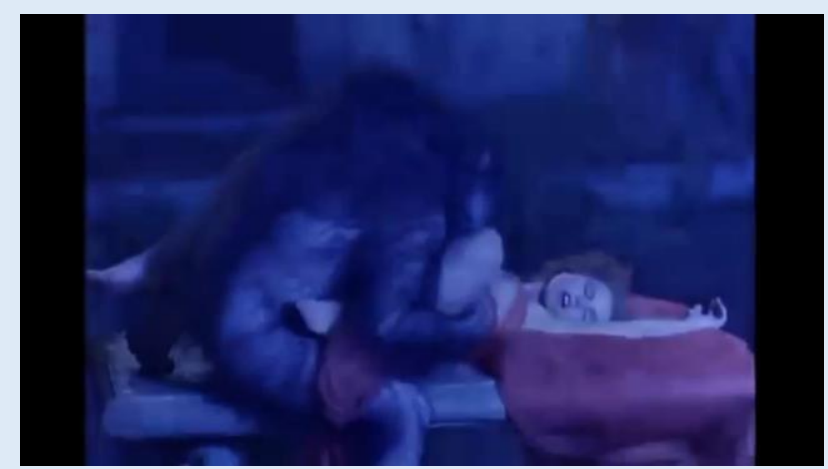

Fonte: captura do filme Bram Stoker's Dracula (1992)

Coppola já assinala um tom romântico em seu filme logo nas primeiras aparições do vampiro. Na cena em que Mina Murray relembra seu passado amoroso com o conde (Fig. 2.2), temos a projeção do "sentimento monstruoso" e do beijo amoroso entre as personagens, a qual reformula a figuração do monstro e (re)cria o processo de empatia do espectador. $\mathrm{O}$ beijo nessa cena é formulado por meio da manipulação e montagem de plano que sai de um enquadramento amplo para um plano fechado em $c u t-i n^{5}$, comumente utilizadas em cenas de beijos, e o uso de músicas de fundo, que induz a leitura da cena como uma cena romântica. Em termos de clichês cinematográficos, na Fig. 2.3 temos o constante uso abusivo de recursos visuais referentes ao terror, como o sangue e violência, os quais também remetem ao processo de exacerbação do monstruoso na figuração do vampiro ao decorrer do cinema.

Figura 2.2: O "beijo" do vampiro.

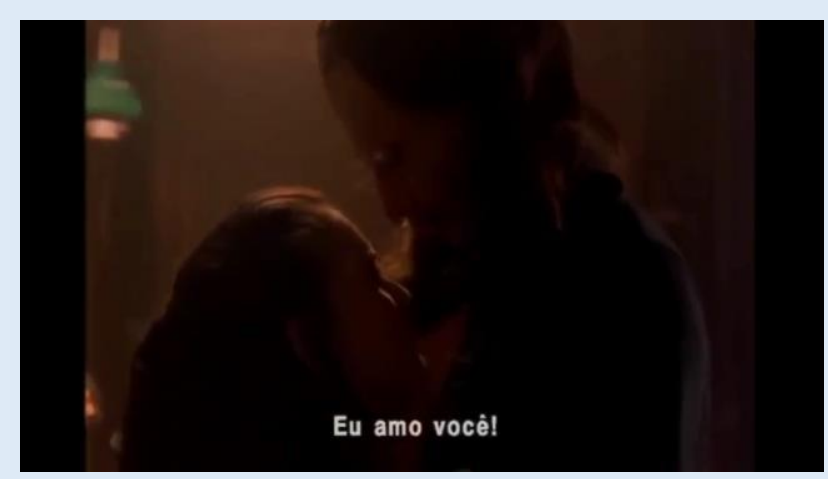

Figura 2.3: Uso exacerbado de sangue e violência.

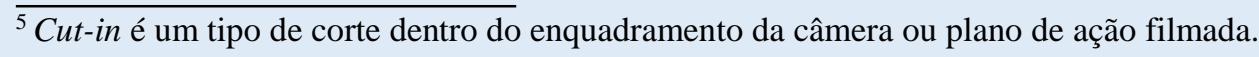

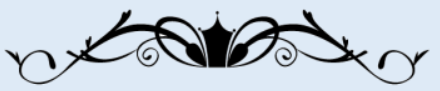




\section{Revista Letras Raras}

ISSN: 2317-2347 - Vol. 8, Ano 4, № 3 - 2015

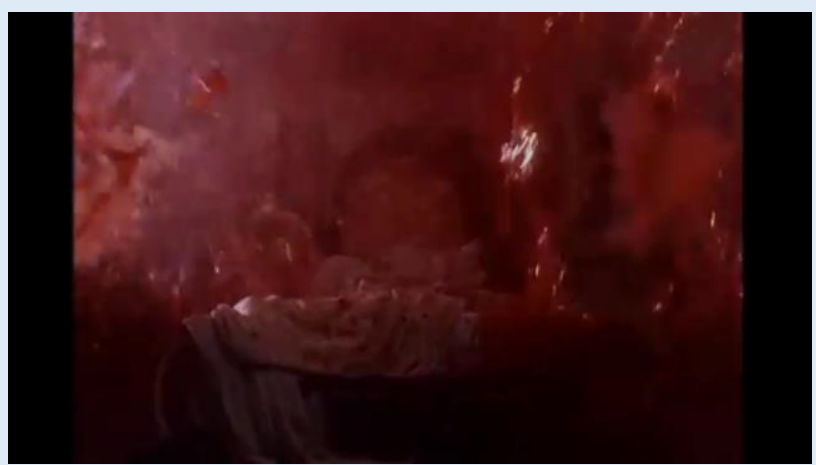

Fonte: captura do filme Bram Stoker's Dracula (1992)

Este recurso de referenciação constante e uso exacerbado de efeitos visuais também é bastante utilizado na série Drácula da NBC Television, que na tentativa de trazer uma nova adaptação do enredo e personagem Drácula para televisão, utiliza recursos e estereótipos do cinema mainstream como uma proposta de novidade. Não é à toa que podemos notar durante os filmes de terror referentes ao vampiro diferentes características hibridizadas de outros gêneros do cinema padrão. A série também retoma o monstro enquanto ser de fronteira que, como apontado por Bellei (2000, p. 20), detém uma função histórica e aspectos emblemáticos de uma alteridade cultural forte, marginalizada e sem lugar, negando sempre sua condição anômala no decorrer do enredo, não conseguindo, assim, integrar-se completamente no sistema dominante de valores ao qual desejava pertencer. Essa alteridade torna-se perceptível quando Drácula/Alexander Grayson toma a figura de um aristocrata estadunidense que se estabelece em Londres para se vingar da ordem do dragão que, por sua vez, é constituída pela nobreza da Londres Vitoriana - a qual a personagem tenta se integrar.

Figura 3.0: Representações temáticas do vampirismo

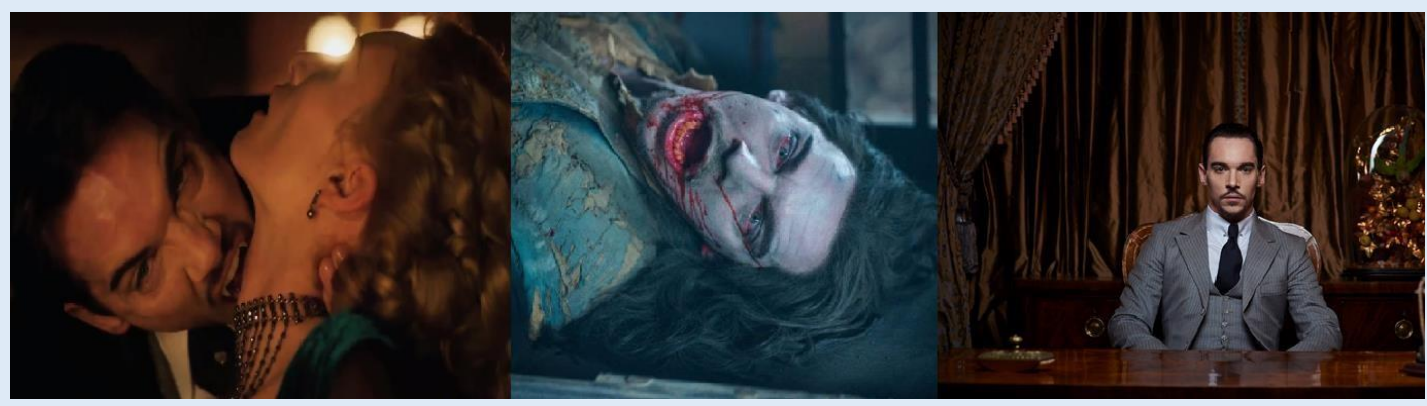

Fonte: captura da primeira temporada da série Dracula (2013)

A alusão de temáticas que estavam sobrepostas na obra Drácula (1897) são emblemáticas de representações fílmicas que se relacionam com o enredo e narrativa da obra.

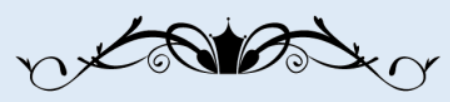




\section{Revista Letras Raras}

ISSN: 2317-2347 - Vol. 8, Ano 4, № 3 - 2015

Como apontado por Johnson (1982, p. 10), a autonomia total da narrativa fílmica é com certeza impossível, pois, ao se propor em adaptar elementos de um romance, o texto literário funciona inevitavelmente como uma forma-prisão para o filme. Ainda segundo Johnson, na maioria dos casos o modelo original é reduzido a um subcódigo do filme, isto é, um léxico comum a certos grupos de falantes de uma língua, porém não a todos. O modelo original representaria, assim, um subcódigo para aqueles que estão cientes dele, isto é, aqueles que leram o livro (JOHNSON, 1982, p.10). Nota-se também que, ao propor a humanização do vampiro, as suas representações iconográficas despontam para outra vertente da monstruosidade desse ser.

Como podemos ver na série de filmes The Twilight Saga, a humanização do vampiro é acentuada por seus dilemas morais e sua iconografia asséptica. No primeiro filme da saga, na cena em que Edward entra no refeitório da escola com seus irmãos vampiros, temos dentro da própria narrativa fílmica, uma sexualidade envolta na personagem Edward, que atrai não só as demais personagens presentes na cena como os futuros fãs espectadores da saga. Assim, o vampiro atinge outro estágio da monstruosidade, a monstruosidade da beleza extrema como “capa” para o mal inerente ao monstro. A capa também é um dos estereótipos constituídos e recorrentes do vampiro ao longo do século XX, porém a capa do vampiro em Crepúsculo é utilizada aqui em seu sentido figurado para cobrir uma monstruosidade desse ser aparentemente humanizado.

Essa humanização que já implica uma monstruosidade, em termos visuais e corpóreos, é verificável no filme Crepúsculo, na cena em que Edward explica e demonstra para Bella Swan os motivos pelos quais este não pode entrar em contato com o sol (Fig. 4), o vampiro apresentado mostra-se totalmente sem pelos, aludindo aos padrões corpóreos e sexuais contemporâneos. Ainda nessa cena há o diálogo entre as personagens Bella e Edward, no qual Bella aponta esse fenômeno, a pele do vampiro brilhando, como algo belíssimo. No entanto, a personagem Edward responde que "aquilo" é a pele de um assassino 6 . Vale destacar, que a palavra skin (pele) é um derivado da palavra $s c i n n^{7}$ que significa cobrir - e no caso da personagem, serve como capa para cobrir a monstruosidade inerente do vampiro. $\mathrm{O}$

\footnotetext{
${ }^{6}$ Assim como apontado na legenda da Fig. 4, Edward responde a Bella: "Beautiful? It's the skin of a killer"

${ }^{7}$ Palavra do Inglês antigo scinn "hide".
}

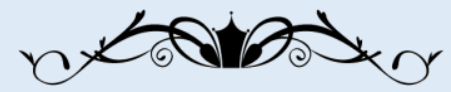




\section{Revista Letras Raras}

ISSN: 2317-2347 - Vol. 8, Ano 4, № 3 - 2015

vampirismo e sua monstruosidade, em Crepúsculo, transgridem a fronteira entre o quadro ficcional e os espectadores, atingindo grande número de adolescentes, na maior parte de sexo feminino, que se identificam com a personagem. Respectivamente, durante os filmes Crepúsculo e Crepúsculo: Amanhecer parte 1, temos as cenas de várias tentativas de atos sexuais da personagem Bella Swan com o vampiro Edward, porém este apresenta dilemas morais, que impedem a consumação do mesmo. Por sua vez, esses dilemas morais estão ligados diretamente com a monstruosidade do vampiro por saber das consequências que a monstruosidade desse implicará.

Figura 4: Beautiful? It's the skin of a killer

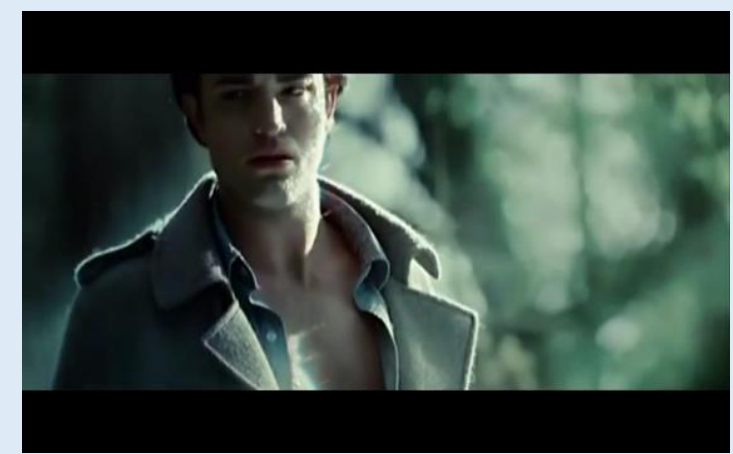

Fonte: captura dos filmes Crepúsculo (2008)

Por fim, é perceptível uma progressão ao longo das cenas citadas e ao decorrer de seus filmes que as representações iconográficas do vampiro retomam temáticas e/ou estereótipos já estabelecidos, mas, as acentuam em diferentes tonalidades. Apesar das acentuações estarem estabelecidas ao longo do trajeto do vampiro no cinema como um procedimento que produz um novo ciclo criacionista do vampiro nos filmes citados. Estes, por sua vez, estruturam-se por meio do controle técnico da narrativa e indústria cinematográfica, sendo moldada preponderantemente por repetições de estruturas e temáticas já decorrentes do cinema mainstream. Assim, não importa o meio pela qual a personagem seja estruturada, mas sim, a finalidade dessa possível nova configuração de vampiro.

\section{Considerações finais}

O presente estudo buscou mapear e analisar as variações de imagem do vampiro Drácula, baseado na hipótese de que, ao longo de suas aparições, a personagem delineada por Stoker e suas características foram ou não exacerbadas na linguagem visual cinematográfica.

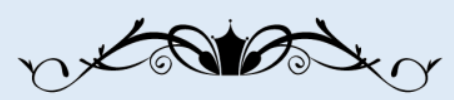




\section{Revista Letras Raras}

ISSN: 2317-2347 - Vol. 8, Ano 4, № 3 - 2015

Pudemos notar que as representações iconográficas tornaram o vampiro muito mais caricato/vampiresco do que os monstros retratados na mídia narrativa anterior por meio de um processo de apropriação e auto referência, reelaborando características recorrentes do imaginário do vampiro. No que diz respeito as repetições feitas ao longo do processo de conversão transmidiática do vampiro linguístico para o vampiro iconográfico e posteriormente entre as próprias representações imagéticas e diversos gêneros do cinema mainstream, Adorno (1994, p. 346) aponta que, ao juntar elementos explorados, a indústria cultural/cinematográfica atribui uma nova qualidade para suas mercadorias. Assim, a indústria cultural/cinematográfica, e as diferentes categorias de gêneros do cinema, fazem-se, mais ou menos segundo um plano, produtos adaptados ao consumo das massas e que em grande medida determinam esse consumo.

\section{Referências Bibliográficas}

ADORNO, Theodor W. Dialética do esclarecimento. Rio de Janeiro: Jorge Zahar Ed., 1985.

ADORNO, T. W. "Televisão, consciência e indústria cultural". In: Comunicação e Indústria Cultural. Cohn, G. (org.). São Paulo: T. A. Queiroz, 1987, p. 346-354.

BELLEI, S. "Definindo o monstruoso: forma e função histórica". In: Monstros, índios e canibais: ensaios de crítica literária e cultural. Florianópolis: Insular, 2000. p. 11-48.

CANDIDO, A. et al. A personagem de ficção. São Paulo: Perspectiva, 2007.

CARVALHO, Bruno (org.). Antologia do vampire literário. São Paulo: Berlendis \& Vertecchia, 2010, p. 15-19.

CALMETE, Agostinho. "Excomungados, os Upiros ou Vampiros, Brucolaques \&". In: . Antologia do vampire literário. São Paulo: Berlendis \& Vertecchia, 2010, p. 27-35.

DUARTE, Rodrigo, Antônio de Paiva. Adorno/Horkheimer \& A dialética do esclarecimento. Rio de Janeiro: Jorge Zahar Ed., 2 ed. 2004.

JOHNSON, Randal. "Romance e filme". In: Literatura e cinema - Macunaíma: do modernism na literature ao cinema novo. Tradução de Aparecida Johnson. São Paulo: T. A. Queiroz, 1982, p. 05-33.

OSSENFELDER, August. "Crê a moça minha amada". In: CARVALHO, Bruno (org.). Antologia do vampire literário. São Paulo: Berlendis \& Vertecchia, 2010, p. 45.

POMMER, Mauro. "O cinema e as mutações de Drácula". In: HAMBURGER, Esther (org.) et all. Estudos de Cinema - Socine, IX. São Paulo: Socine, 2008, p. 25-33.

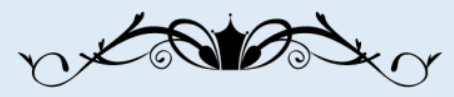




\section{Revista Letras Raras}

ISSN: 2317-2347 - Vol. 8, Ano 4, № 3 - 2015

ROSENFELD, A. Literatura e personagem. In: CANDIDO, A. et al. A personagem de ficção. São Paulo: Perspectiva, 2007, p. 9-51.

STOKER, BRAM. Dracula. San Diego: Canterbury Classics. 2012.

Recebido em: 08/12/2015

Aceito em: 15/12/2015 